\title{
THE EMBEDDEDNESS OF CORE-PERIPHERY RELATIONS IN TIME AND SPACE
}

\author{
Annamaria Simonazzi ${ }^{a}$ \\ aProfessor at the Department of Economics and Law, Sapienza University of Rome. Rome, Italy. \\ ORCID: https://orcid.org/0000-0001-8861-5090.
}

Received on 20 March 2019

Accepted on 19 April 2019

\begin{abstract}
The paper applies the core-periphery approach developed by the Latin American historical-structuralist school to study the consequences of European integration on its peripheral economies. The structural causes of the Eurozone crisis are explained in terms of the divergent trajectories of interdependent economies with different productive capabilities. It is argued that, as in the 1970s, the new challenges confronting the $\mathrm{EU}$ - the digital transformation, new consumption patterns, reversal from globalisation to regional blocs, disenchantment with the European project - call for a radical change in the institutional and productive structures of the Eurozone. Averting the prospect of a disintegrative crisis means revising the European institutions and policies in the direction of a more egalitarian and cohesive Union.
\end{abstract}

KEYWORDS: Eurocrisis; Southern Europe; dependency school; industrial policy.

JEL CODES: F15; O10; O25. 


\section{A INSERÇÃO DAS RELAÇÕES CENTRO- PERIFERIA NO ESPAÇO E NO TEMPO}

RESUMO: O artigo utiliza a abordagem centro-periferia desenvolvida pela escola histórico-estruturalista latino-americana para estudar as conseqüências da integração européia sobre as economias periféricas do bloco. As causas estruturais da crise da zona do euro são explicadas em termos das trajetórias divergentes de economias interdependentes com diferentes capacidades produtivas. Argumenta-se que, assim como na década de 1970, os novos desafios enfrentados pela UE - transformação digital, novos padrões de consumo, inversão da globalização para os blocos regionais, desencanto com o projeto europeu - exigem uma mudança radical nas estruturas institucionais e produtivas da Europa. Evitar a perspectiva de uma crise desintegradora significa rever as instituições e políticas europeias na direção de uma União mais igualitária e coesa.

PALAVRAS-CHAVE: crise do euro; sul da Europa; escola da dependência; política industrial. 


\section{INTRODUCTION}

One of the side effects of the current Eurozone crisis has been the rediscovery of the terms core and periphery to analyse the dynamics of the European integration process in the second half of the 20th century (SIMONAZZI and GINZBURG, 2015; CELI et al., 2018). A second consequence of the crisis, and of the technological transformations that accompanied it, has been the rediscovery of industrial policy.

The differences in the production structure between core and periphery were very considerable at the start of the Europeanization process and many economists had warned that opening the market to competition between countries at different levels of development without adequate countervailing measures would increase divergence (HIRSCHMAN, 1981a). This concern, spearheaded by the European Dependency School (WEISSENBACHER, 2018), was widely shared within the left and part of the mainstream but was eventually ignored. Disregarding the peculiar problems of latecomer countries, the European Union (EU) institutions were shaped on the premise that all its members were on a level playing field, except for certain 'less modern' institutions, individual values and attitudes. The implicit assumption was that an austerity regime, associated with institutions close to those assumed to be prevailing in the 'core' countries, would create the 'right' environment for growth in the periphery (SIMONAZZI and GINZBURG, 2015). Two role models - German disinflation and United States financialization - eventually shaped the process of European integration, leading to monetary integration and global finance.

The demise of the original principles of development economics marked a similar fate for industrial policy. As from the 1980s, early liberalization policies in the periphery prevented public investment guidance. European industrial policy came to be conceived mostly in terms of market selection mechanisms, achieved by enforcing EU competition policy. Thus, over the thirty years of European integration as from the early 1980s, the Southern peripheral countries were exposed to macroeconomic and industrial policy measures that, although apparently neutral, generated increasing regional disparities, both between core and periphery and within countries. Partly as a consequence of their policies, the southern countries' growth fell behind, and the crisis associated with deregulation opened a gap in aggregate demand that was eventually filled by welfare and construction expenditure. This 'premature deindustrialization' restructuring without industrialization - exposed the peripheral countries to stunted growth and persistent fragility in the face of external changes even before the formation of the European Monetary Union (GINZBURG and SIMONAZZI, 2017).

The paper analyses the divergent trajectories of the core and the peripheral European countries in terms of interdependent economies with different productive 
capabilities. After a brief account of the rise and decline of development economics, the next section reviews the analysis conducted by the European Dependency School, which applied the core-periphery approach developed by the Latin American historical-structuralist school to study the consequences of European integration on its peripheral economies. We then use these analytical tools to uncover the structural causes of the Eurozone crisis, which has further increased the core-periphery divergence. As in the 1970s, new challenges - the digital transformation, new consumption patterns, reversal from free trade back to regional blocs, disenchantment with the European project - call for radical change in the institutional and productive structures of the Eurozone. The last section looks at the implications of the current structural transformations for the periphery. We consider whether the prospect of a disintegrative crisis of the Union can prompt settlement of the conflicting interests between and within the member countries, with revision of the European institutions and policies in the direction of a more egalitarian and sustainable union.

\section{THE STRUCTURALIST THEORY OF PERIPHERAL UNDERDEVELOPMENT}

"One of the most conspicuous deficiencies of general economic theory, from the point of view of the periphery" - wrote Prebisch (1950[1949], p. 7) - "is its false sense of universality." Claiming universality, traditional economics extended analysis appropriate to the 'special case' of a minority of developed economies to the underdeveloped countries. The 'monoeconomics' view inspired Rostow's five stages of development, "with identical content for all countries, no matter when they started out on the road to industrialization." By contrast, Gerschenkron's analysis of the process of industrialization in the case of latecomers, such as Germany and Russia, with respect to the British industrial revolution showed that there could be more than one path to development (HIRSCHMAN, 1981b). Different growth styles or 'viable' alternatives were possible within the framework of the capitalist system, and different problems were arising from diverse development modalities (BIELSCHOWSKY, 2016).

Besides the monoeconomics claim, the development ideas that were put forward in the 1940s and 1950s rejected a second ingredient of mainstream economics, namely the mutual benefit claim, i.e. the assertion that economic relations between core and peripheral countries "could be shaped in such a way as to yield gains for both" (HIRSCHMAN, 1981b, p. 3). Different consequences for their economic and institutional structures ensue from the interdependent relations between the two groups of countries. The doctrine of unequal exchange proposed by Prebisch and Singer lent support to the argument for protection and industrialization, while Myrdal's 
and Hirschman's principle of cumulative causation urged the need for public policy to counter polarization. For latecomer countries, industrialization represented a formidable undertaking that could not be left to market forces.

Development economics, therefore, endorsed a stronger steering role for the State in the developing countries than did the mainstream, and new rationales were developed for protection, planning, and indeed industrialization itself. 'Industrial policy' came to identify the set of policies aiming to change the structure of the economy with a deliberate, intensive and guided effort. The economists of the United Nations Economic Commission for Latin America and the Caribbean (known as ECLAC in English, or CEPAL in Spanish and Portuguese) advocated a coordinated policy of import substitution and export promotion; emphasized the pursuit of indigenous 'technological densities' to avoid technological dependence, and stressed the role of the domestic market. Therefore, the opinion that viewed import substitution industrialization (ISI) and export-oriented industrialization (EOI) as two alternative development policies in the CEPAL approach is incorrect $(\mathrm{HO}, 2012)$. The same misconception applies to interpretation of the EastAsian development strategy. With reference to the process of industrialization of Taiwan and China, for instance, Zhu (2006) writes that

The development strategies have always been a combination of ISI and EOI strategies. EOI was used to sustain ISI... Behind this strategy there is a set of institutions which has played a key role in supporting ISI, in particular, the government, the bank sector, public enterprises, and their relationship. (p. 1)

Taiwan's economic success is not so much in selling more goods to the world, but to build a solid industrial base for further development, while lack of a solid industrial base was one of the key problems, which led to the fall of Southeast Asian economies during the Asian financial crisis of 1997. ISI is the key to industrial upgrading as the Taiwan experience shows and which is exactly what Southeast Asian countries have not done or not done enough. (p. 14) ${ }^{1}$

The literature on this issue is vast, and it is beyond our scope to discuss it here. It should be noted, however, that the dynamic interaction between import substitution and export development is at the core of the 'flying geese model,' which is compatible with manifold industrial development models, increasing interdependence in an

Security reasons were behind Taiwan's effort to build its heavy industry in the 1970s and, with US aid dwindling, to engage in EOI to gain the foreign exchange required to finance self-reliance. The need for foreign financing also accounts for China’s open-door policy (ZHU, 2006). 
integrated area, and persistence of asymmetries and hierarchical order across countries (GINZBURG and SIMONAZZI, 2005). ${ }^{2}$

As argued by Hirschman: "[ $t$ ]he difficulties encountered on the path of development, the many failures and dramatic reversals in many countries, exposed the naivete of the idea that progress would be smoothly linear if only [the developing countries] adopted the right kind of integrated development program" (HIRSCHMAN, 1981b, p. 24). Within the development school, these difficulties called for reconsideration of 'social' and 'economic' development 'as a single entity' (SINGER, 1965, p. 4-5). Conversely, external criticism came from two opposite fronts. The neo-Marxist camp (the new dependency theory) stressed that, by attributing underdevelopment only to external circumstances, it exonerated national actors from any responsibility. ${ }^{3}$ On the contrary, the neoclassical camp stressed the risk of misallocation of resources. As from the early 1980s, in the wake of declining Keynesianism, development economics gradually faded away throughout the world and a new orthodoxy for analysing developing economies rapidly emerged, dragging in industrial policy and public intervention in the economy with it. According to the new conventional wisdom, public intervention is only justified when markets fail to produce social optima (due to some form of 'externalities') and the intervention can be expected to move the outcome closer to the social optima at a cost lower than the gain. It then asserts that in the real world, both conditions are rarely satisfied to conclude that "governments cannot pick winners, but losers can pick governments" (WADE, 2012, p. 225).

\section{BACKWASH AND POLARIZATION EFFECTS: CORE-PERIPHERY ANALYSIS IN THE EUROPEAN INTEGRATION}

During the 'glorious 30s' all the European countries in the periphery ${ }^{4}$ recorded highincome growth, led first by investment and consumption, and then by exports. They

2 Lin (2011) maintains that the Flying Geese (FG) model misses an important aspect, namely that catch-up must respect comparative advantage, and this is what differentiates traditional structuralist views from the New Structural Economics. However, his interpretation, reminiscent of Rostow's stages of development, misses the essence of the FG model of industrialisation, which consisted in creating new sectors of comparative advantage, or in Best's words in "how to make critical mass of firms to transition into new sectors” (BEST, 2018, p. 216--217, emphasis added).

3 Traditional Marxists argued that "the dependency paradigm may even turn into an apologetics, namely in defence of the domestic ruling leadership, the local ruling and exploiting classes, exempted from any responsibility" (WEISSENBACHER, 2018, p. 90).

4 I consider here the countries in the Southern European periphery (Greece, Italy, Portugal and Spain). The European Dependency School also considered a North-Western periphery, which included Ireland and Scotland (see SEERS et al., 1979). 
all placed special emphasis on basic industry, deemed necessary for the creation of an industrial sector. The state supported accumulation either directly, through publicly owned companies, or indirectly, through subsidies and incentives to domestic and foreign capital. However, behind the apparent success in growth rates, the pattern of industrialization of the latecomers still exhibited several weaknesses (albeit in differing degrees across countries). Their fragilities were linked to their narrow productive base, their unequal internal development and an unsustainable demand pattern, that resulted in external disequilibria.

In the 1970s and early 1980s a group of scholars used the core-periphery paradigm to analyse the economic conditions and the process of integration in Europe. However, the "core-periphery" term groups together different theoretical approaches. For some authors who have developed dualistic European variants of the 'varieties of capitalism' approach,

center-periphery simply refers to two macro-groups of countries, Northern and Southern EURope, CONSIDERED AS SEPARATE Units of analysis... Analysis of the relations between the centre and the periphery thus becomes secondary, while the focus is only on the characteristics common to the countries belonging to the two groups and on their separate evolution. (SIMONAZZI and GINZBURG, 2015, p. 104)

Similarly, within the mainstream, Krugman (1991) used a core-periphery terminology in his spatial economics, but he did not recognize politico-economic hierarchies or dynamic interrelations. Conversely, the European Dependency School (WEISSENBACHER, 2018) focused on the aspect of dependence in international relations. Emphasizing two basic concepts - interrelations between countries at different levels of development and the crucial role of the productive structure - this approach was critical of the prevailing economic and developmental doctrines, ${ }^{5}$ and extremely pessimistic about the outcome of the European integration process. In Hirschman's words, "[t]hey believed that European integration without a considerable change in Community attitudes and policies would increase divergence and be advantageous to the core countries" (HIRSCHMAN, 1981a, p. 279). This is because, in the absence of countervailing policies, "market forces as well as certain public policies

Weissenbacher (2018, p. 86) notes that the European Dependency School was equally critical of the neoclassical and the Keynesian approaches, on the grounds that the concepts of regional development of the two schools did not differ in their strategies but only in their instruments. Both, at least in the formulation of the neo-classical synthesis, asserted a 'universalistic' and a-historical claim. 
favouring concentration would be given freer play as a result of integration", leaving poorer regions further depleted and exploited (HIRSCHMAN, 1981a, p. 279).

The conclusions of the Dependency School descended from its analysis of the contemporary mode of production, which can be summed up in the following points (WEISSENBACHER, 2018). First, transnational companies had begun to integrate Southern Europe well before the Southern European enlargement of the EC. Their penetration had resulted in monopolistic structures without modernization of industry. Second, integration into transnational capitalism "had aggravated contradictions between traditional and 'modern capitalist elites', which had finally led to the end of dictatorships in Southern Europe" (WEISSENBACHER, 2018, p. 85). However, because of the modern elites' intimate interlocking with international capital, far from leading to a more independent national economy, the pattern of development would result in a more dependent role in the world system (LOGAN, 1985 , p. 150). And third, by giving up the possibility of adopting measures to protect their national economy, in an integrated system the governments of peripheral countries would become highly dependent on those of its core. "If the latter give greater priority to curbing price inflation than to reducing unemployment, there is little the former can do but resign themselves to accepting this priority and shaping their own policies accordingly" (SEERS, 1980, p. 19). Moreover, the construction of an 'institutional laissez-faire system' "would make it difficult for any really left-wing government of the future to exercise controls and carry out far-reaching social changes" (SEERS, 1982, p. 4). Thus, following enlargement and integration between unequal partners, latecomer countries would run into premature deindustrialisation and, in despite of the new democratic liberties, integration in the new international division of transnational capitalism would bring in a new authoritarian statism. Finally, with great foresight, Hadjimichalis noted that, with the fall of the Eastern bloc the southern fringes had lost one important political parameter in their negotiations to avoid disintegrative effects:

German capitalists now have plenty of cheap and well-educated labour from exsocialist countries in situ, and new immigrants are filling blue-collar jobs held by southern Europeans during the 1960s and 1970s. [...] This means that Germans and other central Europeans are no longer willing to pay for the reproduction of cheap labour in the south. (HADJIMICHALIS, 1994, p. 27)

Whilst the new dependency theory had the merit of highlighting the aspects of unequal benefits in international relations, at the same time it appeared to be eminently static, since it did not contemplate any possibility of countertendencies to the 
dependency relations, justifying the label of 'catastrofismo' given to it by Anibal Pinto (HIRSCHMAN, 1981b, p. 18).

Concern over the polarizing effects of the integration between economies with different productive capabilities and severe regional disequilibria was also shared by scholars who did not identify with the Dependency School. Writing in 1979, Hirschman (1981a, p. 278-279) observed that

Whether integration alleviates or aggravates regional disequilibrium and conflict within states has become a major performance test for any project of closer economic and political union among states. The reason is that these persistent disequilibria and conflicts present many states with one of their major contemporary problems. An important argument against integration has therefore been the suspicion that it might aggravate these problems. (emphasis in the original)

In 1962, at the peak of the 'Italian miracle', the Minister of the Budget, Ugo La Malfa, presented to Parliament the 'Nota Aggiuntiva'. In this important document it was argued that Italy's rapid post-war growth had been accompanied by sectoral, regional and social imbalances, and by distortions in the level and the composition of consumption and investment. This analysis prompted the proposal for a plan of coordinated actions which was not based on the market as such, but on its extension and transformation through state support for the creation of new activities. In the political clash that followed, the automatism of stabilization policies eventually prevailed, directing the economy away from indicative planning.

Italy's low per capita income, high unemployment, fragile industrial structure, marked regional differences and high cost and price differentials - which persisted despite the efforts made and the progress achieved - were the reasons that convinced Luigi Spaventa - an authoritative Italian economist elected as independent member of parliament in the Italian Communist Party (PCI) lists - to vigorously oppose Italy's participation in the EMS in the Italian Parliament in 1978 (CELI et al., 2018).

Again in 1980, in a report on "Problems of lagged development in OECD Europe", Fuà (1980) observed - implicitly recalling Gerschenkron's theses - that the structure and tendencies of latecomer European countries were different from those observed during the initial development phases of the older industrialized countries. The major differences concerned the technological gap, the demonstration effect on consumption, and the challenge of competition from more developed countries. These differences translated into strong internal productivity differentials across industries and regions ('dualism'), serious difficulties in providing regular employment to the potential labour supply, higher propensity to price instability and public deficits, and "a peculiar 
fragility of the balance of payments" (SIMONAZZI and GINZBURG, 2015, p. 108). Awareness of the dangers of integration between such unequal partners was very much alive across Southern European countries and led most communist parties of the South to oppose successive steps of integration. ${ }^{6}$ However, political confrontation proved unable to prevent the choice of the alternative development path, which led to integration and premature liberalization.

\section{CUMULATIVE CAUSATION AND PATH DEPENDENCE: THE STRUCTURAL CAUSES OF THE CRISIS}

The crisis of the 1970s, which was associated with saturation of the major mass consumer goods in the advanced countries and the onset of globalization, marked a sharp break in the history of relations between the core and periphery of Europe. It led to profound transformations in demand, production, and competition, which came to be increasingly dominated by the quality of differentiated products rather than by price.

As anticipated by the structuralist school, these changes affected the core and peripheral economies in very different ways. The restrictive monetary policies of the core country exert asymmetric effects on the periphery because of both its monospecialization in commoditized products and the rapid return of capital to the safe-haven centre countries - a phenomenon observed time and again (GINZBURG and SIMONAZZI, 2011), most recently in the Eurozone sovereign crisis (the 'sudden stop'). Moreover, in a context of fixed exchange rates, austerity measures in the periphery are assigned the task of implementing a 'flex-price' policy through domestic devaluation.

The 'centre' succeeded in restructuring its industry, leveraging on the solidity of its system of small and medium enterprises (SME) and with the support of industrial policies, that, even if shunned by academia and the EU, continued to enjoy a very concrete and lively existence, although often 'under the radar', as documented by an increasing number of studies. ${ }^{7}$ The restructuring of the core deeply affected the

6 The Portuguese Communists and the Greek PASOK both opposed their countries' applications for Community membership. The Italian Communist Party opposed Italy's participation in the European Common Market in 1957 and Italy's participation in the European Monetary System in 1979. Yet, by the time the European Monetary Union was created, opposition was to be found only in a relatively small group of heterodox scholars and far-left politicians. See Celi et al $(2018, \mathrm{ch} .1)$ for an account of the theoretical and political U-turn of eminent Italian economists, between the 1970s and the 1980s, on the issue of economic and monetary integration.

7 Although the exact extent and details of Germany's industrial policy are hard to ascertain, given the multiplicity of measures and actors (at the federal, Länder and municipality level), Chang, Andreoni and 
countries of the periphery, ${ }^{8}$ which, in reorganizing their economies, struggled to adapt to the new environment, dominated by disinflation and quality competition. The fall in the relative prices of flex-price items hit their economies harder; their basic industries and 'mature' products faced the competition of the developing countries, calling for drastic cuts in production. The new situation would have required innovation in the state's capacity to guide and facilitate the reorientation of investment so as to respond to a rapidly weakening economic structure. However, on the one hand the structural breaks of the 1970s created extreme uncertainty about the future prospects of international specialization, with paralyzing effects on industrial policy decisions and the prospective growth of industry. On the other hand, their industrial policy, based on state-owned enterprises, direct public investment and subsidies, was more exposed to the scrutiny of the competition arm of the European Commission. Thus, precisely when the state should have been taking on new tasks to ease the process of restructuring, diversification and quality upgrading, these countries adopted acrossthe-board liberalization policies, implementing what might be called 'plain destruction' of their capabilities to create new products, market niches, and markets.

The regime change of the 1980s - privatizations, financialization, labour market reforms and monetary and fiscal discipline - which marked the disappearance of industrial policy and macro economic management, inaugurated the new era of the monetary union. The institutional features of the euro area were not such as to sustain the capacity of the Southern European countries to achieve a sufficient level of diversification and specialization in their productive structures; indeed, they may even have contributed to worsening it, by aggravating the conditions of their poorer regions (although increasing regional dualism did not spare the core). While powerful counterforces were slowing down the pace of the institution-building reforms required to complete the Union, as predicted by Seers, the institutions and reforms already in place pre-empted any alternative policy.

Whilst the economic crisis of the Eurozone has further increased the divergence between the core and the southern periphery, the increasing integration of the Central and Eastern European economies into the supply chain of German industry speeded up their process of diversification and specialization. The eastward integration of German industry, combined with the persistent constraints upon the internal demand

Kuan (2013) rate German industrial policy among the most active in Europe.

8 Describing the difficulties faced by latecomer European countries following the oil shocks, Fuà (1980) observed that they were hurt by the austerity policies and the protectionist measures implemented by core countries in defence of their traditional industries, which compounded the increased competition from developing countries in their products of specialisation. 
of the major economies of the euro area, has gone hand-in-hand with an impoverishment of the productive matrix of those southern regions that are less well connected to Germany and, more generally, with a general redirection of trade flows (SIMONAZZI, GINZBURG and NOCELLA, 2013). Two different industrial models now co-exist: a strong industrial base in core countries, export-oriented and with a strong position on global markets, and a less diversified industrial sector in the periphery. Crisis after crisis, the process of Europeanisation accentuated the hollowing out or impeded the restructuring and growth of the productive structure of Southern countries.

\section{CORE-PERIPHERY RELATIONS IN THE NEW GLOBAL ENVIRONMENT}

As in the 1970s and 1980s, the outbreak of the Eurozone crisis coincided with the development of a new phase in the paradigm of international production and technology. On the one hand, buoyed up by the expansion of Global Value Chains (GVC), the new emerging countries moved their pressure from the lower end to the higher ranks of the product range. On the other hand, new technologies favouring exclusive ownership of the knowledge used in production result in the global monopolization of knowledge and concentration of power. Different competition regimes now coexist: price competition for commoditized products at the lower end of the product scale, oligopolistic competition in the final market of consumer durables, and weak competition, if any, for products and services increasingly bound up with monopolized knowledge along the value chain. How will these changes affect the peripheral countries of the Eurozone? In the following pages, I consider three issues: the nature of competition, the disruption and reorganization entailed by the new technologies, and the role of the domestic market.

\subsection{COMPETITION: FIRMS VS. PRODUCTIVE SYSTEMS}

In the mainstream approach, development is viewed as primarily based on static efficiency, with productivity as the main factor promoting or holding back long-term economic growth. Higher productivity can be achieved by freeing resources tied-up in less efficient firms and redirecting them towards more efficient firms/sectors. It follows that, although well-designed structural reforms of product and labour markets may entail costly adjustments in the short run, in the long run a more efficient allocation of resources will result in greater productivity and growth.

This approach raises two issues. The first concerns the implicit assumption of full employment. Since the existence of sufficient aggregate demand cannot be taken for 
granted, the exit of less productive firms does not guarantee that the freed-up resources will flow towards new, more efficient uses ('creative destruction'). ${ }^{9}$ The increase in productivity will then correspond to a decrease in per capita income, and the ensuing reduction in productive capacity (and employment) will constrain long-term growth. Exclusive focus on the efficient allocation of resources disregards the problem of their utilization, leading to confusing productivity with welfare (proxied by income per capita). If there are idle resources, maximizing productivity is not equivalent to maximizing welfare (SIMONAZZI, CELI and GUARASCIO, 2019).

The second point concerns the underlying theory of the firm or, as Best (2018) put it: "[h]ow growth really happens". Firms do not produce in a vacuum, nor do they develop production capabilities in isolation. What makes regions innovative is not the existence of individual entrepreneurial firms but the presence of clusters of enterprises that collectively act as an industrial experimental laboratory. The performance of firms crucially depends on both the structured interrelationships (the linkages) that they can establish upstream and downstream, and the support received from the material and immaterial infrastructures, universities, research centres, development agencies and financial institutions that sustain the process of innovation in the long term (GINZBURG, 2012). In this context, even 'marginal' firms perform an essential role: they sustain production, employment and income, are part of value chains, produce inputs and innovation, provide training for young workers and contribute towards making the productive fabric thicker and richer, as well as providing flexibility to the system in the cycle (SIMONAZZI, CELI and GUARASCIO, 2019). ${ }^{10}$ It follows that their 'measured' productivity may be the outcome of their place in the value chain or in the economy: as amply demonstrated by many empirical studies, the distribution of bargaining power along the value chain can affect the allocation of productivity (and profits) between the various participating firms. Finally, in an extremely specialised division of labour, there may be good economic reasons for not growing further (DEI OTTATI, 2018). ${ }^{11}$ This is not to say that policies should not target the

9 This point is especially relevant for latecomer countries, as stressed time and again by scholars of development. See for all Fuà (1980, p. 44), who recommended investing in low-productivity sectors, since, if left to themselves, they would succumb and the labour thus displaced would not find alternative employment.

${ }^{10}$ In the last crisis, in Germany adjustment occurred mostly within the firm through working time flexibility; conversely, in Italy, the second-tier suppliers were made to bear the brunt of the collapse in demand and exited the market in large numbers.

${ }^{11}$ Dei Ottati (2018, p. 272) observes that, once they have achieved a sufficient size to perform the functions that enable them to maintain their grip over the market niche in which they operate, medium-sized enterprises generally do not grow any further, as they need to remain flexible so as to adapt to changes in demand and technology. 
firms' efficiency and help them grow, ${ }^{12}$ but exclusive focus on the individual tree can lead to underestimating the long-term economic and social costs for the forest. Shortterm competitiveness resulting from the exit of (less productive) firms can destroy the connective tissue and reduce the productive basis, jeopardising, rather than favouring, long-term growth.

The difference between these two views - the network theory of development (or 'capability triad' in Best's definition) on the one hand and the mainstream approach, based on allocative efficiency and the market mechanism, on the other - has important consequences in terms of policies (as argued below).

\subsection{DIGITAL TRANSFORMATION AND GLOBAL VALUE CHAINS}

The core-periphery polarization may be heightened by the radical change brought about by digitalisation and popularly known as 'Industry 4.0'. Technologies such as Internet of Things, Advanced Manufacturing and Decentralized Artificial Intelligence, designed to renew and reshape manufacturing processes and value chains (VC), are expected to substantially increase efficiency and flexibility in governing production lines and VC. The periphery risks lagging behind, or even falling back further in the industrial race on two grounds. First, since Industry 4.0-related opportunities are maximized when they interact with a closely connected, technologically advanced network, they are likely to thrive in those productive systems that are quicker in developing and absorbing these technologies. Second, full exploitation of new technologies requires digitalization along the entire value chain; thus SME in the supply chain must be helped in adapting their system to digitalize. While close integration will endow value-chain leaders with new instruments to govern production chains, without the accompanying experimentation and technical skills, simply importing technologies and machines may prove inadequate to the task of adaptation to the new organisation of production, which is based on systems integration that operates at both the technological and the organizational levels. Nor is the traditional industrial policy, based on granting subsidies, tax breaks or credit facilities, up to the task any longer. Regional and national systems once thriving on

12 To quote Fuà (1980, p. 50-51) once again, public policy should endeavour to identify those functions in which economies of scale are significant and in which small businesses are disadvantaged, and to ensure that these functions are exercised for them on an optimal scale by appropriate public or private bodies, or through firms' associations and networks. 
incremental innovation can be put to the test. ${ }^{13}$ Core countries are all engaged in the digital race in their various ways: promoting their start-up systems (US), supporting SMEs through platform networks (Germany), utilizing innovative technologies to develop new demand and supply strategies focused on the creation of new products and services (Japan), and using import substitution and the extent of their internal markets to aggressively target new growth sectors (China) (KIM et al., 2018; LEE et al., 2018). Thus, although the fiscal consolidation implemented by the Southern periphery does put their economies at a disadvantage (suffice it to compare the extent of Germany's coordinated effort on its 'Industrie 4.0' plan with Italy's belated efforts (NASCIA, PIANTA and LA PLACA, 2018), success in the new technological race is not only a question of investing in smart machinery or education (though both are necessary). The next step implies extensive industrial and organisational restructuring, policy orientation to help firms identify new opportunities and supportive policies to favour a real integration between science and industry in regional networks of innovation so as to develop the capabilities required by new technologies and products.

\subsection{DOMESTIC AND GLOBAL MARKETS}

Europe must compete in a global market with nations that are actively supporting their industries in the innovation race. To meet this challenge, the European Commission is now endorsing industrial policy in favour of innovation as a whole and advanced technologies in particular. Whilst it encourages cooperation between EU countries, the weaker members are still left to respond to the increasingly difficult environment with 'competitiveness measures' that qualify as beggar-thy-neighbour policies: policies aimed at reducing costs (subsidising labour, investment, R\&D) and attracting foreign direct investment through fiscal competition (tax allowances and various other concessions). Tax incentives are a poor tool to spur innovation, since they have little aggregative impact upon the innovation chain, which is about the activation and coordination of links cutting across governmental, educational, and industrial spheres. Businesses do not

13 According to Best (2018, p. 142), Japan has not been completely successful in transitioning from incremental innovation to systems integration. This may also be the case of the industrial districts of Northern Italy, already weakened by delocalization and competition from low-cost countries in the near and far East, hit hard by the crisis, and "without the intermediate and national technology capability-development institutions of Germany". Although firms have responded to these challenges by increasing their capacity to produce customized products for niche markets and investing in rapidly expanding countries, incremental innovation may be no longer sufficient to tackle the disruption and reorganisation demanded by the new technologies. 
innovate in isolation. Moreover, competitiveness policies aimed at reducing costs are by definition rival: domestic and foreign firms play one country/region off against the other, with negative spill-over effects that represent a dead-weight for society. In the end, they bring a deflationary bias to bear on the economic system.

Is it possible to devise 'progressive' policies capable of improving the capabilities of one country without damaging other countries? In 1960, Myrdal (1960, p. 122) observed that defending the social achievements obtained thus far by the developed countries would require an effort to achieve greater international integration, envisaging the formation of complementary relations in the productive structures of the various countries. Instead of automatisms, that drive the developed countries to adapt to the external pressures of the market with heavy job losses, he advocated a state-driven structural adjustment, designed to 'make room' for the industrial exports that the developing countries will be prepared to produce.

The world does not seem to be going in that direction, nor does the European Union. Protectionist threats are looming large, envisaging a world newly split into regional blocs, increasingly dominated by the US and China. Within the European Union, years of austerity in debtor countries, increasing inequality and disappointed expectations are feeding populism and acrimony towards the European project. To many, it is no longer a matter of if, but of when the disintegrative crisis will occur. Is it still possible to avert this crisis? That is, can the pressure of the current challenges finally force the development of 'countervailing forces', capable of transforming the 'disintegrative crisis' that leads the individual members to go it alone into an 'integrative crisis' that, on the contrary, impels members to look for some concerted action? ${ }^{14}$ This development would require nothing short of a U-turn in European policies, at both the macroeconomic and the industrial level. Preventing the digital transformation from becoming an additional factor of polarization would call for massive investments in the weakest areas, aimed at strengthening infrastructure facilities, industrial capabilities and technological transfer. Awareness of the threats entailed by uneven adoption of Industry 4.0 across Europe ${ }^{15}$ has not yet translated into concrete actions. The largest Europe-wide action plan - the Juncker Plan - is far from ensuring a balanced diffusion of Industry 4.0 technologies.

A new, more cohesive, industrial policy could not succeed without a U-turn in macroeconomic philosophy. The EU should focus on the development of demand and

\footnotetext{
14 See Hirschman (1981a, p. 283).

15 See, for example, the European Parliament Industry 4.0 briefing (EC, 2015) and the analytical study commissioned by the European Parliament in 2016 (EC, 2016).
} 
supply strategies that place greater reliance on the domestic market, at the EU and national level. Export-led (or neo-mercantilist) policies clearly disrupt the long-term sustainability of a union and are meeting with increasing hostility at the international level. Opportunities and proposals in this direction are not lacking: long-term investment plans in physical and social infrastructure which prioritize the most deprived regions, a Marshall Plan for European recovery, a 'golden rule' for credit-financed public investment. The provision of public goods for the productive sector can offer new opportunities for innovative firms, while exerting a strong activating capacity. Public services exhibit rapid growth in demand in cities and metropolitan areas. The focus on welfare as an engine for growth calls for systemic action at different levels of governance (national, regional, municipal) and institutions to coordinate the supply and demand of innovative services. In the changed international environment, a greater weight attributed to domestic demand at the EU level will also suit the surplus countries.

\section{CONCLUSION}

EU survival is threatened by internal and external disrupting forces. The institutional features of the EU and the Euro area did not work in the direction of reducing the inequalities between its core and peripheral members state, which the economic crisis then aggravated. The accelerated pace of technical change raises a further threat for latecomer countries: the institutions and infrastructures that populate the innovative productive systems are not to be found in the case of Southern Europe. To fill the coreperiphery divide, public-private cooperation should contemplate a combination of protection, administrative guidance, and encouragement of controlled competition to activate linkages and fill the gaps in the productive structure. Introduction of a 'protective' element - that is 'helping losers' by temporarily shielding them from the full forces of the market - may be needed to encourage and sustain the process of structural change and productivity growth, as well as preserving existing capabilities while allowing time to develop new ones, developing new products also within 'mature' sectors. This should not be confused with the traditional industrial policy, which often tried to preserve existing structures (CHANG, ANDREONI and KUAN, 2013). ${ }^{16}$ Finally, the EU needs to respond to geo-political turbulence by redefining its policy. As

\footnotetext{
${ }^{16}$ It is emblematic that France and Germany are proposing to loosen antitrust rules and protect 'national champions' from foreign takeovers, so that they can compete with Chinese behemoths and US digital monopolists (see THE ECONOMIST, 2019).
} 
Seers wrote at the start of the Europeanization process (SEERS, 1979, p.29-30), "a policy of collective 'self-reliance' would strengthen European bargaining power, reduce dependence on the US and other outside powers, and lessen the risk of Europe being drawn into war". We have now come full circle back to the questions and problems debated by the development economics of the 1950s and 1960s, with the important difference that we are now facing a difficult, potentially disintegrative crisis. We can only hope that the prospect of the precipice succeeds in mobilizing sufficiently strong counteractive forces. ${ }^{17}$

\section{REFERENCES}

BDI - BUNDESVERBAND DER DEUTSCHEN INDUSTRIE. Partner and systemic competitor - how do we deal with China's state-controlled economy? BDI, 2019. Available at: <https:// english.bdi.eu/publication/news/china-partner-and-systemic-competitor/>.

BEST, M. How growth really happens. Princeton: Princeton University Press, 2018.

BIELSCHOWSKY, R. "Fifty years of ECLAC thought: a review”. In: BIELSCHOWSKY, R (Org.). ECLAC Thinking. Selected Texts (1948-1998). Santiago de Chile: ECLAC, 2016, p. 7-44.

CELI, G. et al. Crisis in the European Monetary Union. A core-periphery perspective. London: Routledge, 2018.

CHANG, H.-J.; ANDREONI, A.; KUAN, M. L. International industrial policy experiences and the lessons for the UK. Future of Manufacturing Project: Evidence Paper 4, Foresight, Government Office for Science, 2013.

DEI OTTATI, G. Marshallian industrial districts in Italy: the end of a model or adaptation to the global economy? Cambridge Journal of Economics, v. 42, p. 259-284, 2018.

EC - EUROPEAN PARLIAMENT. Briefing Paper on Industry 4.0. Satisfactory Project, October 12, 2015. Available at: <http://www.satisfactory-project.eu/satisfactory/europeanparliament-briefing-paper-on-industry-4-0/2015>.

EC - EUROPEAN PARLIAMENT. Industry 4.0. Study for the ITRE Committee. EC, 2016. Available at: <http://www.europarl.europa.eu/RegData/etudes/STUD/2016/570007/IPOL_ STU(2016)570007_EN.pdf>.

${ }_{17}$ Under the heading "A strong and united Europe" the BDI (Bundesverband der Deutschen Industrie, the Federation of German Industries) writes: “The EU is the world's largest single market in terms of GDP. The EU should translate this economic strength more into political self-confidence, especially vis-à-vis China and the US. Only a strong and united Europe can defend its interests and values against the emerging world power of China... Key words here are the deepening of the economic and monetary union, the strengthening of research, innovation and industry, the further development of the internal market, the orientation of the EU budget towards growth, cohesion and external strength, and the expansion of the digital economy" (BDI, 2019, p. 10-11). 
FUÀ, G. Problems of lagged development in OECD Europe. A study of Six Countries. Paris: OECD, 1980. (Italian translation 1985. Bologna: Il Mulino)

GINZBURG, A. Sviluppo trainato dalla produttività o dalle connessioni: due diverse prospettive di analisi e di intervento pubblico nella realtà economica italiana. Economia \& Lavoro, v. 2, 2012.

GINZBURG, A.; SIMONAZZI, A. Patterns of industrialization and the flying geese model: the case of electronics in East Asia. Journal of Asian Economics, v. 15, p. 1051-1078, 2005.

GINZBURG, A.; SIMONAZZI, A. "Disinflation in industrial countries, foreign debt cycles and the costs of stability”. In CICCONE, R.; GEHRKE, C.; MONGIOVI, G. (Eds.). Sraffa and modern economics. London: Routledge, 2011, p. 269-296.

GINZBURG, A.; SIMONAZZI, A. Out of the crisis. A radical change of strategy for the euro zone. European Journal of Comparative Economics, v. 14, n. 1, p. 13-37, 2017.

HIRSCHMAN, A. O. “Three uses of political economy in analysing European integration”. In: HIRSCHMAN, A. O. Essays in Trespassing. Economics to Politics and Beyond. Cambridge: Cambridge University Press, 1981, p. 266-284, 1981a[1979].

HIRSCHMAN, A. O. “The rise and decline of development economics”. In: HIRSCHMAN, A. O. Essays in Trespassing. Economics to Politics and Beyond. Cambridge: Cambridge University Press, 1981b[1979], p.1-24.

HIRSCHMAN, A. O. Essays in Trespassing. Economics to Politics and Beyond. Cambridge: Cambridge University Press, 1981.

HO, P. S-W. Revisiting Prebisch and Singer: beyond the declining terms of trade thesis and on to technological capability development. Cambridge Journal of Economics, v. 36, p. 869-893, 2012.

KIM, G. et al. The fourth industrial revolution in major countries and its implications of Korea: U.S., Germany and Japan Cases. KIEP Research Paper, World Economy Brief, v. 8, n. 20, p. $1-5,2018$.

KRUGMAN, P. R. Geography and trade. Cambridge, Mass.: MIT press, 1991.

LEE, H. T. et al. China's manufacturing development and its implications for Korea. KIEP Research Paper, World Economy Brief, v. 8, n.18, p. 1-5, 2018.

LIN, J. Y. From flying geese to leading dragons. New opportunities and strategies for structural transformation in developing countries. Policy Research Working Paper, World Bank, n. $5702,2011$.

LOGAN, J. "Democracy from above. Limits to change in Southern Europe". In: ARRIGHI, G. (Ed.) Semiperipheral development. The politics of Southern Europe in the Twentieth Century. Beverly Hills, CA: Sage, 1985, p. 149-177.

MYRDAL, G. Beyond the Welfare State: economic planning and its international implications. London: Taylor \& Francis, 1960.

NASCIA, L.; PIANTA, M.; LA PLACA, G. RIO Country Report 2017: Italy. EUR 29189 EN. Luxembourg: Publications Office of the European Union, 2018. 
PREBISCH, R. The Economic Development of Latin America and its principal problems. Economic Survey of Latin America 1948. New York: United Nations Department of Economic Affairs, [1949]1950. Available at: <https://repositorio.cepal.org/bitstream/handle/11362/30088/ S4900192_en.pdf? sequence $=1$ \&isAllowed $=y>$

SEERS, D. “The periphery of Europe”. In: SEERS, D.; SCHAFFER, B.; KILJUNEN, M. (Eds.) Underdeveloped Europe: studies in core-periphery relations. Hassocks: The Harvester Press, 1979 , p. 3-34.

SEERS, D. “Theoretical aspects of unequal development at different spatial levels". In: SEERS, D.; VAITSOS, C. (Eds.) Integration and the unequal development. The Experience of the EEC. London: Macmillan, 1980, p. 9-23.

SEERS, D. "Introduction". In: SEERS, D.; VAITSOS, C. (Eds.). The integration of unequal partners. The Second Enlargement of the EEC. London: Maxmillan, 1982, p. 1-21.

SIMONAZZI, A.; GINZBURG, A.; NOCELLA, G. Economic Relations between Germany and Southern Europe. Cambridge Journal of Economics, v. 3, p. 653-675, 2013.

SIMONAZZI, A.; GINZBURG, A. “The interruption of industrialization in Southern Europe: A center-periphery perspective”. In: BAUMEISTER, M.; SALA, R. (Eds). Southern Europe? Italy, Spain, Portugal, and Greece from the 1950s until the Present Day. Frankfurt: Campus, 2015, p. 103-137.

SIMONAZZI, A.; CELI, S.; GUARASCIO, D. “Developmental industrial policies for convergence within the European Monetary Union”. In: HERR, H.; PRIEWE, J.; WATT, A. (Eds.) Still time to save the euro. Berlin: Social Europe Publishing, 2019, p. 162-183.

SINGER, H. W. Social development: key growth sector. International Development Review, v. 7, n. 1, p. 3-8, 1965.

THE ECONOMIST. Engine trouble. The Economist, Finance and Economics, February 9, p. 5657, 2019.

WADE, R. H. Return of industrial policy? International review of applied economics, v. 26, n. 2, p. 223-239, 2012.

WEISSENBACHER, R. Peripheral integration and disintegration in Europe: the European dependency school' revisited. Journal of contemporary European Studies, v. 26, n. 1, p. 81-98, 2018.

ZHU, T. Rethinking import-substituting industrialization. Development Strategies and Institutions in Taiwan and China. UNU-WIDER Research Paper, n. 76, 2006. 